\title{
Transdisciplinarity and protected areas: A matter of research horizon
}

\section{Ulli Vilsmaier}

Keywords: transdisciplinarity, objectives of protected areas, types of protected area research, research and target horizons, embeddedness of protected areas in society

\section{Abstract}

This article discusses the consequences and challenges for protected area research resulting from the changes and diversifications of the idea of area protection. The article provides an overview of the diverse types of protected area research and a critical analysis of the potentials and limits of newly emerging forms of research, such as involving stakeholders. The main question raised is to what extent protected area research can be conceptualized in a transdisciplinary way. A short introduction to the discourse on transdisciplinarity will be followed by an analysis of possibilities for conceptualizing protected area research in a transdisciplinary mode. It will be shown that the full potential of the newly emerging form of research can be tapped by orienting protected area research towards different target horizons and by strengthening the embeddedness of protected areas in society.

\section{Introduction}

During recent decades, the idea of area protection has undergone various transformations in terms of aims, tasks and functions (Mose 2007). The main shift consists of overcoming the dichotomy between territories for nature protection and spaces for human activities. While the isolation of beautiful landscapes and endangered species was an initial motive for area protection, the idea of protection has developed towards a wider understanding of preserving the ecosystem as a whole. The concept of passive protection has evolved into an active approach aimed at societal transformations in accordance with sustainable development. Today, an integrative perspective on conservation and societal development is widely acknowledged and expressed in (inter)national policies, the diversification of protected area (PA) objectives and in the establishment of PAs that aim at balancing protection and human activities to ensure sustainable development (Hammer 2007a). Area protection is turning into an all-embracing issue and project for society as a whole.

These transformations do not only require an adaptation of policies but also challenge protected area research and call for adjusting and expanding research perspectives and subjects. In fact, research issues related to PAs are increasing ultimately and new modes of research are emerging. For instance, participatory research approaches are becoming more common in $\mathrm{PA}$ research and the term transdisciplinarity appears more frequently in publications related to PA research, in research concepts and policy papers of protected areas to underline its relevance to society.

Developing a transdisciplinary research mode currently challenges different scientific communities and policy makers as it goes against the grain of consolidated institutional structures and traditional research methodologies. By reflecting knowledge production and established social roles against an ample background of societal requirements, the need for transformation within science as well as in the relation between sci-

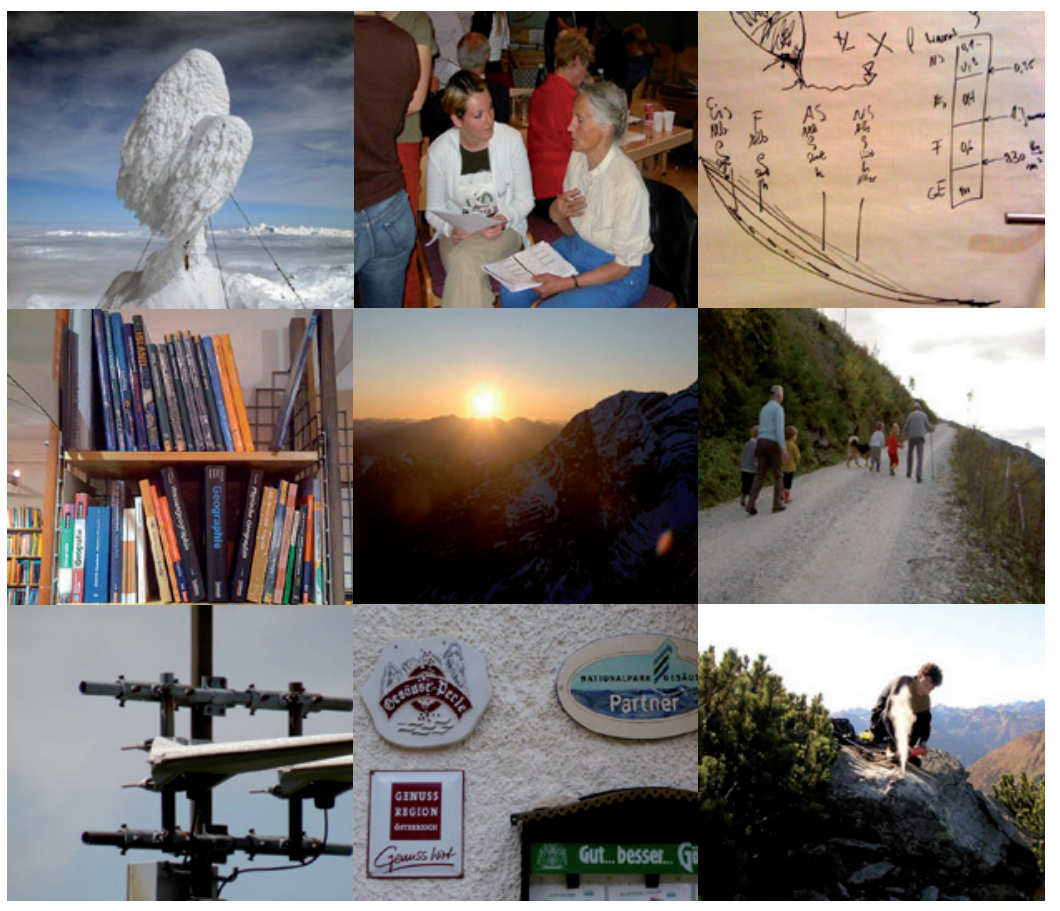

Figure 1 - Research in, on and for protected areas. (C) Ulli Vilsmaier

ence and other domains of society becomes visible. This article analyses possibilities to conceptualize PA research in a transdisciplinary mode. A short introduction to the discourse and practices of transdisciplinarity will be followed by an overview of target horizons of area protection and types of PA research. Further, it will be shown that transdisciplinarity is not established by simply integrating non-scientific stakeholders into a discipline-based research design. Benefits of transdisciplinary organization of PA research will be discussed in terms of science and society.

\section{Transdisciplinarity}

Due to the problems we are dealing with at the beginning of the $21^{\text {st }}$ century, the need for new modes of research and cooperation between different disci- 
plines and societal domains is becoming more urgent. The search for a new type of research, of knowledge production and problem transformation is based on difficulties and lack of success in dealing with complex so-called real-world problems of society (Hirsch Hadorn et al. 2008). In context, the use of the term transdisciplinarity has increased enormously since the 1990s (Kueffer et al. 2007). Transdisciplinarity is called for in all fields of human interaction with natural systems (Klein 2004). But the debate on and practice of transdisciplinary research is still very young and to some extent unclear (Zierhofer \& Burger 2007; Pohl \& Hirsch Hadorn 2006; Jahn 2005).

The idea of transdisciplinarity originates in a change of perspective. Research questions within the field of human interaction with the biosphere should no longer arise from a disciplinary point of view, but should rather be derived from real-world situations with a need for change. The primacy of the problem requires an adaptation of research, as historically grown disciplinary structures usually do not meet the problems' complexity. Here, transdisciplinarity primarily addresses the framing of problems and the identification of research questions. Instead of merging subjects of research that have been created within a disciplinary tradition, "it would be urgently necessary to discover and construct entirely new subjects of research." (Stehr 2005: 355; Translation: UV). According to Hirsch Hadorn et al. (2008: 30) "there is a need for transdisciplinary research when knowledge about societal relevant problem fields is uncertain, when the concrete nature of problems is disputed, and when there is a great deal at stake for those concerned by problems and involved in dealing with them."

The main difference in the debate relates to the question of how this can be achieved. Some authors consider it a task to be solved within science by reorganizing the internal structures and equate it with 'true interdisciplinarity', that goes beyond temporary cooperation (Mittelstraß 2003). Transdisciplinarity is regarded as an integrative concept that seeks to overcome disciplinary isolations at a higher methodological level. Many other authors, however, do not only question the internal structure but also the system of knowledge production as a whole (e.g. Gibbons et al. 1994; Nowotny 1999; Scholz 2000; Klein et al. 2001; Zierhofer and Burger 2007; Hirsch Hadorn et al. 2008). They question the exclusive academic form of research and advocate the integration of non-scientific perspectives and experiences by integrating stakeholders into research processes. Especially in environmental sciences, the integration of non-scientific perspectives on and experiences of real-world situations is strongly advocated. Scientific knowledge production is regarded as one specific form and perspective to frame and analyse a problem containing complementary dimensions which should be integrated in order to obtain a more complete understanding and create more useful and accepted solutions. As society is constituted by com- plex processes of accessing, experiencing, perceiving and interpreting the world, many transdisciplinary approaches demand for this multiplicity to be taken into consideration.

This understanding of transdisciplinarity leads to the widespread idea and practice of integrating stakeholders in knowledge production processes (e.g. Zierhofer \& Burger 2007; Klein 2004; Scholz 2000). The integration of stakeholders' perspectives, knowledge, desires and interests addresses different motivations: first, a higher quality of research results is expected by augmenting the sources of knowledge and perspectives. Secondly, participatory research is often seen as a mutual learning process and thirdly, a higher acceptance and success implementing research results is expected (Klein et al. 2001, Stoll-Kleemann \& Welp 2008). However, if stakeholder integration turns out to be highly significant, equating transdisciplinarity with stakeholder participation only would be a reduction of the potential the discourse on transdisciplinarity opens up.

\section{A matter of horizons}

A key for reorganizing research in a transdisciplinary mode is framing research according to different target horizons to disclose the multiple dimensions of phenomena that need to be understood and transformed. Below I shall outline an approach that overcomes the adherence to existing traditions of science (Stehr 2005) and integrates perspectives and dimensions that are not captured by traditional scientific approaches. MaxNeef (2005: 7f) suggests organizing transdisciplinary research by combining different levels and purposes of accessing the world to create not only knowledge but also transformation capability for sustainable development. He distinguishes the following questions:

- What exists? (Empirical level)

What are we capable of doing? (Pragmatic level)

What do we want to do? (Normative level)

- What should we do? Or: How should we do what we want to do? (Value level)

According to Max-Neef, transdisciplinary research is based on the coordination of all four levels. He suggests integrating different scientific disciplines, addressing those levels (including philosophy \& ethics) in research processes. But if we deal with real-world problems against the background of these empirical, pragmatic, normative and value-related questions, research turns out to be more than scientific knowledge production. It then becomes a societal learning and negotiation process, where roles are distributed according to the abilities and experiences of the stakeholders involved. A research process of this kind is not simply divided into an active and passive side, strictly separating the subject and the object of research, but rather forms part of the required transformation and does not only provide knowledge for others to implement. In this way, transdisciplinarity questions 
the epistemological core of modern science (Nowotny 1999), which is based on separation from society (Latour 2002). Constructing an overall transdisciplinary research framework by relating research fields to different target horizons allows for overcoming this separation without degrading disciplinary and interdisciplinary research. It is a complementary approach that creates space for adopting traditional forms of research by including not only attributes of concern but also diverse perspectives, interests, perceptions and sources of knowledge to foster transformation ability. Below I shall explore to what extent PA research can be conceptualized in a transdisciplinary mode, integrating empirical, pragmatic, normative and valuerelated aspects.

\section{Transformations of PA objectives and their consequences on $\mathrm{PA}$ research}

As shown above, the claims for a new production of knowledge arise from the lack of success in changing current misguided developments. Looking to area protection, McNeely (2008) accurately points out that the primary objective of the protected area movement, i.e. conserving biodiversity, has not been met. According to the Red List of Endangered Species, acceleration in loss of biodiversity can still be observed and the main challenges for PAs are still increasing. These are population growth and dynamics, (inter)national insecurity and resulting pressures on PAs from migration or the primacy of economic considerations in decision-making processes. McNeely concludes that PAs face two major issues: "uncertainty, ranging from local politics to climate change, economic conditions and geopolitics; and values, guiding relations with neighbours, visitors, and decision-makers, compounded by the dilemma as to whose values should dominate" (ibid.: 105).

Experiencing and acknowledging these circumstances and challenges, the PA idea has undergone a change which often is interpreted as a paradigmatic shift. While protection from humans was the principal idea at the beginning of the PA movement, the need for area protection with humans has since become obvious. 'The 'ecology first' perspective is based on the protection of nature by the exclusion of people. The new paradigm, the 'people first' perspective, looks to a direct cooperative relationship between the integrity of ecosystems and the sustainable livelihood of local people." (Stoll-Kleemann \& Job 2008: 87). Aims of area protection have diversified and developed a stronger orientation towards society. As Scheurer (2004) points out, the human dimension of area protection was discovered. On the one hand, area protection is more intensively discussed as an idea and concept responding to human impact on the biosphere. By reflecting its embeddedness in society, the realization of the idea turns out to be a project of society (at least in democracies). On the other hand, the transterritorial human impact on PAs through economic activities and lifestyle (e.g. polluting emissions, global warming, soil sealing, construction of landscape barriers) leads to a challenge not only in managing PAs, but also for research, taking these influences into consideration as context factors. The ongoing paradigmatic shift is a challenge that does not only call for new practices in managing PAs, but also for rethinking concepts of PA research.

The initial research tasks of PAs were predominantly oriented towards conservation and protection of the biosphere (e.g. diversity of species, monitoring of species' development and habitats) and the investigation of natural phenomena in largely unaffected territories (PAs as 'open-air laboratories'). Human activities were relevant as context factors only. Besides basic research, applied research targets were oriented towards management tasks of PAs. Discovering the human dimensions of area protection, research on the relation between humans and PAs has ultimately been increasing (see, for instance, Conference Proceedings National Park Hohe Tauern 2005, 2009, summarizing research activities from different research institutions). Analysed issues include the acceptance and perception of PAs, the influence on regional development, education about environment and sustainability and fields of conflicts between different objectives of PAs as well as economic impacts. Such research activities offer important insights for management tasks in PAs and should strengthen PA objectives in society, especially if positive economic impacts can be demonstrated or acceptance rates in local population turn out to be high. However, not every research activity within these thematic fields can be regarded as PA research. For instance, economic valuation of protected areas (mainly tourism) has little to do with the idea of area protection, even if it includes recreation and environmental education which are often embedded in economic valuation concepts.

The paradigmatic shift is also reflected in new modes of research. Participatory approaches have increased worldwide in research on and management of PAs (Stoll-Kleemann \& Welp 2008; Reutz-Hornsteiner 2009). Apart from participatory elements in disciplinary or interdisciplinary research (usually to capture context factors), it has become more common to integrate stakeholders with a view to a better realization of PA objectives, including mutual learning processes and, depending on the type of PA, to jointly develop target horizons and strategies for their implementation. Especially in PAs with weak legislative regulation, such as biosphere reserves, participatory approaches have become very important and many examples show the success of integrative, participatory implementation and management processes (see, for instance, the case of Entlebuch Biosphere Reserve, Hammer 2007b). An outstanding example of participatory research is the Wienerwald Biosphere Reserve, where research for sustainable wildlife management was carried out in a participatory, cross-sectional manner, integrating 
Table 1 - Types of PA research in PAs with a strong legal status. (C) Ulli Vilsmaier

\begin{tabular}{|c|c|c|}
\hline Type & Dimension & Subject (examples) \\
\hline \multirow{3}{*}{ Research in PAs } & Research on natural phenomena (general) & $\begin{array}{ll}\text { - } & \text { Species traits; } \\
\text { - } & \text { sediment budgets; } \\
\text { - } & \text { detection of vegetation patterns. }\end{array}$ \\
\hline & Research on natural phenomena (single case) & $\begin{array}{l}\text { - } \quad \text { Habitat mapping; } \\
\text { - } \quad \text { monitoring of species. }\end{array}$ \\
\hline & Global change survey & $\begin{array}{ll}\text { - } & \text { Monitoring of hydrological systems; } \\
\text { - } & \text { reaction scenarios of permafrost sites; } \\
\text { - } & \text { landscape dynamics. }\end{array}$ \\
\hline \multirow{2}{*}{ Research for PAs } & Research for management tasks & $\begin{array}{l}\text { - Surveys for visitor flow control, zoning; } \\
\text { - } \quad \text { wild life management. }\end{array}$ \\
\hline & Research on conflicting PA aims & $\begin{array}{l}\text { - Conservation vs. recreation/education/research activities; } \\
\text { - } \quad \text { wilderness vs. cultural landscapes. }\end{array}$ \\
\hline \multirow{2}{*}{ Research on PAs } & Research on ecological impact aims & $\begin{array}{l}\text { Transterritorial analysis of habitats; } \\
\text { - comparative studies between PAs and non-PA territories; } \\
\text { - } \quad \text { efficiency of ecological networks. }\end{array}$ \\
\hline & Research on impact of PA in society & $\begin{array}{l}\text { - } \quad \text { Acceptance, perception; } \\
\text { - identity and community building; } \\
\text { - } \quad \text { impact on regional development. }\end{array}$ \\
\hline \multirow{3}{*}{$\begin{array}{l}\text { Context related } \\
\text { research }\end{array}$} & $\begin{array}{l}\text { Spatial (human impact and natural system } \\
\text { dynamics) }\end{array}$ & $\begin{array}{l}\text { Economic valuation of PAs; } \\
\text { - economic activities influencing the PA (e.g. emission, landscape } \\
\text { barriers); } \\
\text { - } \quad \text { transterritorial natural system dynamics. }\end{array}$ \\
\hline & Historical (territorial, exterritorial) & $\begin{array}{l}\text { - Former land use of PAs; } \\
\text { - influence of former human activities. }\end{array}$ \\
\hline & $\begin{array}{l}\text { Context analysis: socio-cultural, political, eco- } \\
\text { nomic (local, regional, national, international) }\end{array}$ & $\begin{array}{l}\text { - Implementation processes (governance); } \\
\text { - } \quad \text { perceptions of nature; } \\
\text { - economic conditions of people. }\end{array}$ \\
\hline
\end{tabular}

researchers from various disciplines and a multitude of stakeholders from different types of land use (Reimoser et al. 2008; Brandenburg et al. 2009).

In PAs with a strong legal status and severe restrictions (such as national parks), however, the challenge of working with people turns out to be much more difficult and contradictory. The paradox is simply explained: from the PA perspective, people are enemies and should be partisans at the same time (McNeely 2008). The symbol of the paradox is the border (Vilsmaier \& Mose 2005). Borders were constructed as "lines of defence between people and the natural resources many of them (especially the rural poor) want to use." (McNeely 2008: 105). Now, that decades of experiences in area protection have shown that defending PAs by obligations and regarding people as enemies is not a sustainable solution, we are struggling with the proper concept. This is an obstacle in participatory approaches, whether they are oriented towards management or research tasks and it can be an obstacle in communicating the PA idea to society. In decisionmaking processes, an equality of partners cannot be pretended as the margin for decisions is defined by the legal basis and the declared aims (Wallner et al. 2008). In participatory PA research, the same contradiction is inherent, at least if research activities follow predefined, normative aims (which would not be the case if participation was targeted only at gathering information). These conditions have to be taken into account when exploring possibilities of conceptualizing PA research in a transdisciplinary way.

\section{Conceptualizing transdisciplinary PA re- search}

In order to conceptualize PA research in a transdisciplinary mode, the research horizon has to be oriented towards the overall objective of area protection, which is, very generally, a balanced relation of man and biosphere. It opens up a framework for integrating particular objectives of area protection, even contradictory ones. Furthermore, it allows for integrating not only empirical questions into the research process, but also pragmatic, normative and value oriented questions. By relating research activities to different target horizons of area protection, increased transparency of the importance of PA research activities can be achieved. This can be useful for communicating the PA idea to the public and for participatory approaches in research by underlining the meaning of stakeholders' contributions to research processes. Moreover, it contains the potential to transform or complement disciplinary or interdisciplinary research. The contextualization of particular research activities within the overall idea of area protection can be strengthened by researchers and by research coordinators of PAs. It is one reason among many why a coordinated process for research activities in PAs is crucial. Outlining cross-sectional issues in research concepts (as realized in the research concept of the Swiss National Park \& Biosphere Reserve Val Müstair 2008-2018, Forschungskommission SNP 2008) is a constructive step towards establishing a transdisciplinary research perspective in particular research activities.

This very basic step of framing PA research with respect to different target horizons to develop a 
transdisciplinary research perspective can be deepened by distinguishing types of PA research. Apart from distinguishing between rationalities and organizational forms of research (science/humanities; disciplinary / inter- or transdisciplinary research), PA research also differs depending on its relation to PAs as either research in PAs, on PAs, for PAs or context-related research (see Table 1).

Research in PAs aims at investigating the biosphere under no or reduced human impact to gain insight on the biosphere, including comparative studies and research on global change phenomena. It is, in principle, natural science organized in disciplinary, multi- and interdisciplinary ways and provides answers at the empirical level (What exists?). The relation to the overall objective mainly consists in providing knowledge on the biosphere for a better understanding of natural phenomena and the impacts of human activities. If participatory approaches are applied, they are contextrelated and aimed at gathering information on human impacts.

Research for PAs primarily aims at supporting management tasks. Research is oriented towards territory-related aims of PAs such as conservation, investigation, recreation and education. With regard to the multiplicity of goals, disciplinary, multi- and interdisciplinary approaches from natural science and the humanities are required. Compared to research in PAs, it clearly addresses defined purposes and provides information for managing PAs. As PA aims can be contradictory in themselves (e.g. conservation vs. recreation; wilderness vs. historically grown cultural practices), research for PAs helps minimizing conflicts. If participatory approaches are applied, they are primarily oriented towards realizing predefined aims. Research for PAs is based on empirical research results and addresses the pragmatic level (What are we capable of doing?) as well as a dimensions of the value level (How should we do what we want - and have(!) - to do?). The more general dimension of what should be done as well as the normative question (What do we want to do?) are, to a large extent, predefined by the PA concept and institutionalized rules and not part of negotiation processes.

Research on PAs refers to the concept and the project as a whole. It is an integrative perspective that does not focus on either the PA territory or the PA context. Research on PAs studies the social and ecological impact of PAs, the realization of PA objectives and critically reflects the conception and implementation of area protection as a whole. It is aimed at continuously developing formal and conceptual foundations of area protection. This type of research directly meets the overall objective of area protection and addresses all target horizons. Area protection here is conceived as a societal project aimed at providing adequate solutions for the man and biosphere relation that makes it necessary to integrate scientific research results, different societal perspectives, experiences and interests. Thus, research on PAs requires transdisciplinary approaches. Depending on the specific purposes, the space for transdisciplinary research can be opened up for temporary or constant collaboration. Research with a limited temporal horizon can be organized through defined activities such as project panels or steering committees (e.g. Reimoser et al. 2008; Freyer and Muhar 2006). Methods for integrating different types of knowledge, perception and for linking negotiation processes to research range from structured dialogue to complex qualitative and quantitative integration methods such as scenario techniques or multi-criteria analyses and assessment methods (for an overview of transdisciplinary integration methods and examples see, for instance, Bergmann et al. 2010). Longterm research processes, however, call for integration through structural changes, such as research platforms and scientific boards of PAs. For all steps of transdisciplinary research (according to Hirsch Hadorn et al. 2008: problem identification and structuring, problem analysis, bringing results to fruition), a manifold structural embeddedness of PAs is crucial, especially at regional level. It also allows incorporating empirically gained knowledge and management purposes into the wider society, including (public) discourses, administrative structures and political institutions. If constant communication and information exchange is given, transdisciplinary research activities can build on these structures. Again, as PAs have an institutional body, including the role of research coordination, transdisciplinary research approaches can be advanced through strengthening those structures and roles.

So far, two steps towards conceptualizing PA research in a transdisciplinary mode have been outlined. First, a systematization and relation of particular research to different target horizons of area protection holds the potential of rethinking and reframing disciplinary or interdisciplinary research fields by linking them to horizons that go beyond immediate scientific interests or management tasks. Even if the core research activity is pure science, the contextualization within the wider horizon of the PA idea is a valuable surplus as its relevance for society becomes visible. Second, research on PAs is outlined as an integrative level of PA research that allows the integration of knowledge, perspectives and interests through temporal activities, structural and institutional changes.

\section{Outlook}

Because of their institutional body, PAs offer an adequate basis for orienting PA research more and more towards transdisciplinarity. In fact, several research concepts of national parks that were studied for this survey give a higher importance to embedding PA research more deeply into a wider field of society. This can be realized by establishing or strengthening research platforms and scientific boards of PAs, including stakeholders from different areas of society and 
research institutions. An outstanding example is the research concept of the Swiss National Park \& Biosphere Reserve Val Müstair 2008-2018. As the key for realizing this vision and strengthening established practices, the success will depend on the willingness of all parties involved, i.e. political and administrative institutions, organizations of civil society and economic institutions and, in particular, research institutions. The more embedded a PA is within society at a structural level, the better the chances not only for communicating the idea of area protection and research results but also for creating space for transdisciplinary research, from framing problems to producing knowledge and creating solutions that enjoy the support of the wider society.

Individual researchers or research groups can contribute by contextualizing particular disciplinary or interdisciplinary research activities in PAs more strongly, relating them to different target horizons of the PA idea. Contextualizing particular research activities will also help to make its specific relevance for society more visible and easier to argue, which can contribute to consensus-oriented decision-making processes of PA management and to foster societal learning processes. Finally, as many authors record, the prerequisite for successfully establishing transdisciplinary research is respecting and exploring the diversity of perspectives, regarding diversity as an advantage, not a handicap (Pohl et al. 2008). Occasionally, this means leaving predefined paths, searching for mutual understanding at different organizational levels (terminology, theoretical foundation, methodology of research, values and norms) and creating space for integration.

To conclude, a theoretical reflection on possibilities for conceptualizing PA research in a transdisciplinary mode aims at pointing out horizons that are opened up by the discourse on transdisciplinarity. But in the end it is the practice of science that will decide on the project of transdisciplinarity, its potential and power of transformation, not meta-theoretical reflections (Stehr 2005).

\section{References}

Bergmann, M., T. Jahn, T. Knobloch, W. Krohn, Ch. Pohl \& E. Schramm 2010. Methoden Transdisziplinärer Forschung. Ein Überblick mit Anwendungsbeispielen. Frankfurt a. M., New York.

Brandenburg, Ch., W. Lexer, F. Reimoser, R. Zink, F. Heckl, A. Bartel, A. Muhar \& H. Tomek 2009. Participative research to develop integrated approaches for a sustainable wildlife management in the Biosphere Reserve Wienerwald. In: Conference Volume $4^{\text {th }}$ Symposium of the Hohe Tauern National Park for Research in Protected Areas (September 17-19, 2009, Kaprun Castle): 39-40. Kaprun.

Forschungskommission SNP 2008. Forschungskonzept 2008-2018 - Schweizerischer Nationalpark und Biosphera Val Müstair. Available at: http://www.
nationalpark.ch/tasks/sites/de/assets/File/Reihe_ nationalparkforschung.pdf (accessed: 20/09/10).

Freyer, B. \& A. Muhar (eds.) 2006. Transdisziplinäre Kooperation in der universitären Ausbildung. Die Fallstudie ,Leben 2014' in der Nationalparkeregion Hohe Tauern/Oberpinzgau. Wien.

Hammer, T. 2007a. Protected Areas and Regional Development: Conflicts and Opportunities. In: I. Mose (ed.), Protected Areas and Regional Development in Europe. Towards a New Model for the 215t Century: 21-39. Hampshire, Burlington.

Hammer, T. 2007b. Biosphere Reserves: An Instrument for Sustainable Regional Development? The Case of Entlebuch, Switzerland. In: I. Mose (ed.), Protected Areas and Regional Development in Europe. Towards a New Model for the 21st Century: 39-54. Hampshire, Burlington.

Hirsch Hadorn, G., H. Hoffmann-Riem, S. BieberKlemm, W. Grossenbacher-Mansuy, D. Joye, Ch. Pohl, U. Wiesmann \& E. Zemp 2008. The Emergence of Transdisciplinarity as a Form of Research. In: G. Hirsch Hadorn, H. Hoffmann-Riem, S. Bieber-Klemm, W. Grossenbacher-Mansuy, D. Joye, Ch. Pohl, U. Wiesmann \& E. Zemp (eds.), Handbook of Transdisciplinary Research: 19-39. Berlin.

Jahn, T. 2005. Soziale Ökologie, kognitive Integration und Transdisziplinarität. Technologiefolgenabschätzung - Theorie und Praxis 14 (2): 32-38.

Klein, J.T., W. Grossenbacher-Mansuy, R. Häberli, A. Bill, R.W. Scholz \& M. Welti (eds.) 2001. Joint Problem Solving among Science, Technology and Society - An Effective Way for Managing Complexity. Basel, Boston, Berlin.

Klein, J.T. 2004. Prospects for transdisciplinarity. Futures 36: 515-526.

Kueffer, Ch., G. Hirsch Hadorn, G. Bammer, L. van Kerkhoff \& Ch. Pohl 2007. Towards a Publication Culture in Transdisciplinary Research. GAIA 16 (1): 22-26.

Latour, B. 2002. Die Hoffnung der Pandora. Untersucbungen zur Wirklichkeit der Wissenschaft. Frankfurt a. M.

McNeely, J.A. 2008. Protected Areas in a World of Eight Billion. GAIA 17 (S 1): 104-106.

Max-Neef, M. 2005. Foundations of transdisciplinarity. Ecological Economics 53: 5-16.

Mittelstraß, J. 2003. Transdisұiplinarität - wissenschaftliche Zukunft und institutionelle Wirklichkeit. (=Konstanzer Universitätsreden 214). Konstanz.

Mose, I. (ed.) 2007. Protected Areas and Regional Development in Europe. Towards a New Model for the $21^{15 t}$ Century. Hampshire, Burlington.

Mose, I. (ed.) 2009. Wahrnehmung und Akzeptanz von Großschutzgebieten. (=Wahrnehmungsgeografische Studien Bd. 25). Oldenburg.

Nationalpark Hohe Tauern 2005. Conference Volume $3^{\text {rd }}$ Symposium of the Hohe Tauern National Park for Reserach in Protected Areas (September 15-17, 2005, Kaprun Castle). Kaprun.

Nationalpark Hohe Tauern 2009. Conference Volume $4^{\text {th }}$ Symposium of the Hohe Tauern National Park for Reser- 
ach in Protected Areas (September 17-19, 2009, Kaprun Castle). Kaprun.

Nowotny, H. 1999. Es ist so. Es könnte auch anders sein. Über das veränderte Verbältnis von Wissenschaft und Gesellschaft. (=Erbschaft unserer Zeit. Vorträge über den Wissensstand der Epoche 4). Frankfurt a. M.

Pohl, Ch., L. v. Kerkhoff, G. Hirsch Hadorn \& G. Bammer 2008. Integration. In: G. Hirsch Hadorn, H. Hoffmann-Riem, S. Bieber-Klemm, W. Grossenbacher-Mansuy, D. Joye, Ch. Pohl, U. Wiesmann \& E. Zemp (eds.), Handbook of Transdisciplinary Research: 411-426. Berlin.

Pohl, Ch. \& G. Hirsch Hadorn 2006. Gestaltungsprinzipien für die transdis₹iplinäre Forschung. Ein Beitrag des tdnet. München.

Reimoser, F., W. Lexer, Ch. Brandenburg, R. Zink, F. Heckl, A. Bartel, B. Ferner \& A. Muhar 2008. Integriertes nachhaltiges Wildtiermanagement im Biosphärenpark Wienerwald. Endbericht des $\mathrm{MaB}$ Projekts ,Integrated Sustainable Wildlife Management in the Biosphere Reserve Wienerwald - ISWI-MAB'. Available at: http://hw.oeaw.ac.at/ISWIMAB (accessed: 20/09/10).

Reutz-Hornsteiner, B. 2009. How can PAs offer local people a chance to participate and benefit? In: Conference Volume $3^{\text {rd }}$ Symposium of the Hohe Tauern National Park for Research in Protected Areas (15.-17.9.2005, Kaprun): 275-277. Kaprun.

Scheurer, T. 2004. Auch der Nationalpark hat ,Human Dimensions'. In: Schweizerische Akademie der Geistes- und Sozialwissenschaften, Bulletin 2: 44-45. Bern.

Scholz, R.W. 2000. Mutual learning as a basic principle of transdisciplinarity. In: R.W. Scholz, R. Häberli, A. Bill \& M. Welti (eds.), Transdisciplinarity: Joint problemsolving among science, technology and society. Proceedings of the International Transdisciplinarity 2000 Conference. Workbook II: Mutual learning session: 13-17. Zürich.

Stehr, N. 2005. Von der Zukunft der Wissenschaftskulturen und den Bedingungen der Transdisziplinarität. In: M. Döring, W. Settekorn \& H. v. Storch (eds.), Küstenbilder, Bilder der Küste. Interdisziplinäre Ansichten, Ansätze und Konzepte: 351-360. Hamburg.

Stoll-Kleemann, S. \& H. Job 2008. The Relevance of Effective Protected Areas for Biodiversity Conservation: An Introduction. GAIA 17 (S 1): 86-90.

Stoll-Kleemann, S. \& M. Welp 2008. Participatory and Integrated Management of Biosphere Reserves - Lessons from Case Studies and a Global Survey. GAIA 17 (S 1): 161-167.

Vilsmaier, U. 2009. Conceptualizing protected area research in a transdisciplinary mode. In: Conference Volume $4^{\text {th }}$ Symposium of the Hohe Tauern National Park for Research in Protected Areas (September 17-19, 2009, Kaprun Castle): 317-320. Kaprun.

Vilsmaier, U. \& I. Mose 2005. The Implementation of the National Park Idea in Society - The Role of Agenda 21 Processes. In: Conference Volume $3^{\text {rd }}$ Sympo- sium of the Hohe Tauern National Park, for Research in Protected Areas (September 15-17, 2005, Kaprun Castle): 239-243. Kaprun.

Wallner, A., U. Schüpbach \& U. Wiesmann 2009. Managing a World Heritage Site - Potentials and Limitations of Transdisciplinary Approaches. In: Conference Volume $4^{\text {th }}$ Symposium of the Hohe Tauern National Park for Research in Protected Areas (September 17-19, 2009, Kaprun Castle): 333-336. Kaprun.

Zierhofer, W. \& P. Burger 2007. Transdisziplinäre Forschung - ein eigenständiger Modus der Wissensproduktion? Problemorientierung, Wissensintegration und Partizipation in transdisziplinären Forschungsprojekten. GALA 16 (1): 29-34.

\section{Author}

\section{Ulli Vilsmaier}

is a social geographer at the Department of Geography \& Geology of Salzburg University. Her current research and teaching focuses on inter- and transdisciplinary research, participation methods, area protection and regional development as well as the anthropological constitution of space.

University of Salzburg, Department of Geography and Geology, University of Salzburg, Research Group Social Geography, Hellbrunnerstraße 34, 5020 Salzburg, Austria.

ulli.vilsmaier@sbg.ac.at 